\title{
THE OCCURRENCE OF AMPHIBIANS IN BROMELIADS FROM A SOUTHEASTERN BRAZILIAN RESTINGA HABITAT, WITH SPECIAL REFERENCE TO Aparasphenodon brunoi (ANURA, HYLIDAE)
}

\author{
TEIXEIRA, R. L., ${ }^{1}$ SCHINEIDER, J. A. P. ${ }^{2}$ and ALMEIDA, G. I. ${ }^{2}$ \\ ${ }^{1}$ Museu de Biologia Prof. Mello-Leitão, Av. José Ruschi, 4, Centro, CEP 29950-000, Santa Teresa, ES, Brazil \\ ${ }^{2}$ Curso de Pós-graduação em Biologia Animal, UFES, Dep. Biologia, \\ Av. Marechal Campos, 1468, CEP 29040-090, Vitória, ES, Brazil \\ Correspondence to: Rogério L. Teixeira, Rua Bernardino Monteiro, 75, Centro, CEP 29650-000, \\ Santa Teresa, ES, Brazil, e-mail: rogeteix@terra.com.br \\ Received January 18, 2001 - Accepted May 23, 2001 - Distributed May 31, 2002
}

(With 2 figures)

\begin{abstract}
Five species of anuran amphibians, all belonging to the family Hylidae, were collected at Praia das Neves, municipality of Presidente Kennedy, southeastern Brazil,. The species were represented by four genera: Scinax, Hyla, Aparasphenodon, and Trachycephalus. Four species (A. brunoi, Hyla albomarginata, Scinax altera, and S. cuspidatus) were found during the dry season (August 1999), and two (A. brunoi and Trachycephalus nigromaculatus) in the rainy season (February 2000). Aparasphenodon brunoi was the most abundant species in Praia das Neves. Some reproductive aspects and feeding habits of this hylid were investigated. Aparasphenodon brunoi was found mainly inside the bromeliad Aechmea lingulata, the largest plant analyzed. Fifteen specimens were collected during the dry season (August 1999) (11 males and 4 females). During the rainy season (February 2000), we collected 14 specimens ( 3 males, 10 females, and 1 juvenile). Sex-ratio was 1:1. Frogs ranged in snout-vent length from 31.2 to $69.3 \mathrm{~mm}$. Females were larger than males. One female had 1,451 fully developed oocytes in her ovaries. The major groups of prey found in the stomachs were: Insecta, Myriapoda, and Arachnida. Blattodea, Orthoptera, Lepidoptera, and Hymenoptera (only ants) were the main food types in frequency, number, and weight. Aparasphenodon brunoi is a threatened species in many habitats of southeastern Brazil. Only natural vegetation protection may guarantee its survival during the immediate future.
\end{abstract}

Key words: diet, fecundity, sex-ratio, bromeliad, sandy coastal plain.

\section{RESUMO}

A ocorrência de anfíbios anuros em bromélias de restinga do Sudeste do Brasil, com referência especial a Aparasphenodon brunoi (Amphibia, Hylidae)

Cinco espécies de anfíbios anuros ocorreram em bromélias localizadas na restinga de Praia das Neves, Município de Presidente Kennedy, Sudeste do Brasil, as quais pertenceram a quatro gêneros: Aparasphenodon, Hyla, Scinax e Trachycephalus. Quatro espécies (A. brunoi, Hyla albomarginata, Scinax altera e $S$. cuspidatus) foram coletadas durante o período seco (agosto de 1999), mas somente duas (A. brunoi e Trachycephalus nigromaculatus) durante o período de chuva (fevereiro de 2000). Aparasphenodon brunoi foi a espécie mais representada e é um anfíbio anuro que se esconde durante o dia, principalmente dentro da bromélia-tanque Aechmea lingulata. A dieta e alguns aspectos da fecundidade desse hilídeo foram investigados. Quinze exemplares foram coletados durante o período de seca (agosto de 1999) (11 machos e 4 fêmeas) e 14 (3 machos, 10 fêmeas e 1 juvenil) durante o período de chuva 
(fevereiro de 2000). A razão sexual total macho/fêmea foi de 1:1. Aparasphenodon brunoi variou no comprimento rostro-anal de 31,2 a 69,3 mm. Fêmeas eram maiores do que os machos. Apenas uma fêmea tinha ovários com ovócitos completamente desenvolvidos, em um total de 1.451 ovócitos. Os principais grupos de presas encontrados nos estômagos foram: Insecta, Myriapoda e Arachnida. Blattodea, Orthoptera, Lepidoptera e Hymenoptera (só formigas) representaram as principais presas de A. brunoi, tanto na freqüência de ocorrência quanto no número relativo de presas ingeridas e no peso. Aparasphenodon brunoi é uma espécie ameaçada de extinção em diferentes habitats no Sudeste do Brasil. Somente a proteção da cobertura vegetal de seus ambientes naturais poderá garantir a existência desse hilídeo nos próximos anos.

Palavras-chave: dieta, fecundidade, razão sexual, bromélias, restinga.

\section{INTRODUCTION}

Some amphibian species use bromeliads strictly for shelter, while others use them during the entire life cycle, reproducing and feeding inside the plant axil (Peixoto, 1995). The Bromeliaceae constitute a large family composed mainly of epiphytes, most of them belonging to the phytotelm type with rosulate ramets where enough leaf litter and rainwater accumulate to support aquatic life (Dejean \& Olmsted, 1997). Particularly in the sandy coastal plain of Brazil, most bromeliads are terrestrial and abundant, conferring some unique characteristics on the vegetation of that habitat. The restinga offers a variety of microhabitats allowing the colonization by many amphibian species (Silva et al., 2000).

Aparasphenodon brunoi Miranda-Ribeiro (1920), the main subject of the present study, is an anuran amphibian characterized by an unequal osseous top of the head which, incrusted in the cranium (helmet-like), protects the species against predators when inside the axil of bromeliad tanks or bamboo holes. This osseous morphology is called hyperossification, and can affect the external dermal investing of the skull bones (Duellman \& Trueb, 1994).

Exclusively Brazilian, this species occurs on the sandy coastal plains of the States of São Paulo, Rio de Janeiro, and Espírito Santo (Frost, 1985; Haddad, 1998), and has recently also been recorded in the Rio Doce State Park, Minas Gerais (Feio et al., 1998) and in Una, on the Bahian coast (Argôlo, 2000). Haddad (1998) pointed out that populations of A. brunoi are declining in the State of São Paulo, mainly due to the destruction of the vegetation covering the sandy coastal plain. According to Feio et al. (1998) A. brunoi is also a species threatened by extinction in the southeasthern State of Minas Gerais.

Little information exists on the amphibian community living inside bromeliads, and even less about the ecology of $A$. brunoi. This study aimed at providing information on reproductive aspects and the diet of this frog. Some amphibian species, including Aparasphenodon brunoi were sampled in bromeliads on the sandy coastal plains of Praia das Neves. We also discuss the importance of developing plans for protecting the natural habitat of this frog and other anurans, since the populations may be declining due to antropogenic interference.

\section{MATERIAL AND METHODS}

Amphibians were collected by hand in August 1999 (dry season), and in February 2000 (rainy season) at Praia das Neves (ca. $21^{\circ} 15^{\prime} \mathrm{S}, 40^{\circ} 56^{\prime}$ W). Samples were taken in a single day. Praia das Neves is a small resort, with potential for growth within the next few years. Frogs were collected during the diurnal period (between 8:00 and 18:00 h) from bromeliads located next to the sandy beach. We examined bromeliads of the following species: Vriesea sp. $(\mathrm{n}=63)$, Neoregelia sp. $(\mathrm{n}=62)$, Aechmea lingulata (123), and A. nudicaulis $(\mathrm{n}=23)$. They were cut close to the ground, shaken upside down, and replanted whenever possible.

The anuran specimens collected were immediately preserved in $10 \%$ formalin, injected intraperitoneally in order to minimize digestion. Specimens were then labeled and placed in plastic bags. After a week, they were washed and transferred to $70 \%$ alcohol. In the laboratory, preserved Aparasphenodon brunoi were measured for snoutvent length (SVL in $\mathrm{mm})$, weighed $(0.01 \mathrm{~g}$ precision), and sexed (except for one individual, classified 
as juvenile, as it could not reliably be sexed. The number of eggs inside female oviducts was counted. Stomach contents were removed and identified as to taxonomy. Total number and wet weight $(0.1$ mg precision) of prey types and their relative occurrence were used as a food preference measure. Intact prey was measured with a caliper. Covariance analysis was used to compare the slopes in the length/weight relationship between sexes. Sex was the independent value; weight, the dependent variable; and length, the covariant. Voucher specimens of the amphibians were deposited in the zoological section of Museu de Biologia Prof. Mello Leitão (MBML), located in the municipality of Santa Teresa, Espírito Santo.

\section{RESULTS}

Few amphibians were found inside the bromeliads at Praia das Neves. The five species collected belong to the family Hylidae (Table 1), represented by four genera: Scinax, Hyla, Aparasphenodon, and Trachycephalus. Four species were found during the dry season (Aparasphenodon brunoi, Hyla albomarginata, Scinax altera, and S. cuspidatus), and two (A. brunoi and Trachycephalus nigromaculatus) during the rainy season. Total anuran abundance was low, increasing slightly during the dry season (winter). All species collected use bromeliads as a diurnal shelter only. Depressions in the sand become an important water reservoir where a variety of tadpoles can be found during the rainy season. Anthropogenic influence in the area is clear, since garbage deposits can be found everywhere, mainly during the summer vacations.

Aparasphenodon brunoi was not an abundant species at our study site, although it was the species best represented among the amphibians collected. It was found mainly inside Aechmea lingulata, the largest bromeliad analyzed. The species selects the larger bromeliads, which probably offer safer shelter than the smaller ones. Also, A. lingulata may retain a greater water volume than the other bromeliads, thus proportioning perhaps offering more adequate moisture conditions for sheltering A. brunoi during the day, when temperatures may reach $40^{\circ} \mathrm{C}$ during the summer. Besides that, $A$. brunoi is too big to hide in small bromeliads. The specimens collected were practically immobile, which suggests that $A$. brunoi is active during the night, since death feigning has very often been observed as a defensive behavior of this species.

TABLE 1

Number of anuran species collected at Praia das Neves restinga habitat during dry season (August 1999) and rainy season (February 2000).

\begin{tabular}{|l|c|c|}
\hline \multicolumn{1}{|c|}{ Species } & Dry season & Rainy season \\
\hline Aparasphenodon brunoi Miranda-Ribeiro, 1920 & 15 & 14 \\
\hline Hyla albomarginata Spix, 1824 & 1 & - \\
\hline Scinax alterus B. Lutz, 1973 & 10 & - \\
\hline Scinax cuspidatus A. Lutz, 1925 & 7 & - \\
\hline Trachycephalus nigromaculatus Tschudi, 1838 & - & 1 \\
\hline Total & $\mathbf{3 3}$ & $\mathbf{1 5}$ \\
\hline
\end{tabular}

Fifteen specimens were collected during the dry season (11 males and 4 females), and fourteen (3 males, 10 females, and 1 juvenile) during the rainy season. Total male/female ratio was $1: 1$. Frogs ranged in size from 31.2 to $69.3 \mathrm{~mm}$ SVL. Females were larger than males (Fig. 1). However, the slopes were not significantly different between sexes (ANCOVA: $\mathrm{F}_{1,25}=1.17 ; \mathrm{p}=0.289$ ).
Only one female had ovaries containing fully developed oocytes, which numbered 1,451. This female had $69.3 \mathrm{~mm} \mathrm{SVL}$, and weighed $18.97 \mathrm{~g}$. The ovary (with eggs) weighed $3.74 \mathrm{~g}$, representing $19.7 \%$ of the total body mass. This specimen was collected during the dry season. Other specimens showed a variety of oocyte developmental stages. 


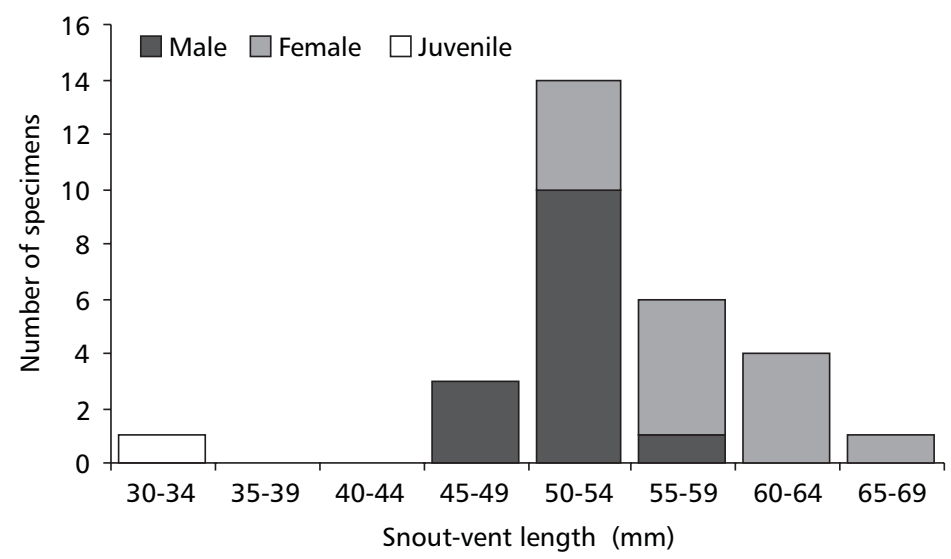

Fig. 1 - Snout-vent length distribution of A. brunoi from bromeliads of a restinga habitat in southeastern Brazil.

The female specimens collected during the rainy season all had flaccid ovaries, suggesting that they had already spawned, probably releasing their eggs in the pools formed on the sand.

Twenty-nine specimens had their stomachs analyzed; of these, eight were empty. We found twelve different types of prey in the stomachs of A. brunoi (Table 2). The main groups were: Insecta, Myriapoda, and Arachnida. Major food items in frequency, number, and weight were Blattodea, Orthoptera, Lepidoptera, and Hymenoptera (only ants).

Prey varied in size from 4.1 to $65.0 \mathrm{~mm}$ of total length $($ mean $=22.7 ; \mathrm{SD}=19.4)($ Fig. 2$)$. There was no significant relationship between prey and frog sizes. A. brunoi ingested both small and large prey, independently of snout-vent length; Chilopoda was its largest prey.

TABLE 2

Types of prey found in the stomach of $A$. brunoi $(n=21)$ of southeastern Brazil. F.O. = Frequency of occurrence; $N=$ number of prey; $\mathrm{W}=$ prey wet weight.

\begin{tabular}{|c|c|c|c|}
\hline Prey type & \%F.O. & $\% \mathrm{~N}$ & $\% \mathrm{~W}$ \\
\hline \multicolumn{4}{|l|}{ INSECTA } \\
\hline Blattodea & 14.3 & 11.1 & 18.3 \\
\hline Orthoptera & 14.3 & 11.1 & 13.1 \\
\hline Hemiptera & 9.5 & 14.8 & 10.1 \\
\hline Coleoptera & 4.8 & 3.7 & 0.2 \\
\hline Hymenoptera (ants) & 19.0 & 25.9 & 1.0 \\
\hline Lepidoptera (larvae) & 9.5 & 7.4 & 36.4 \\
\hline Insect remains & 9.5 & - & 0.4 \\
\hline \multicolumn{4}{|l|}{ MYRIAPODA } \\
\hline Diplopoda & 4.8 & 3.7 & 0.1 \\
\hline Chilopoda & 14.3 & 14.8 & 6.6 \\
\hline \multicolumn{4}{|l|}{ ARACHNIDA } \\
\hline Araneae & 9.5 & 7.4 & 13.1 \\
\hline \multicolumn{4}{|l|}{ OTHERS } \\
\hline Shed skin & 9.5 & 7.4 & 0.5 \\
\hline Vegetable remains & 4.8 & - & 0.1 \\
\hline Total & - & 27 & - \\
\hline
\end{tabular}




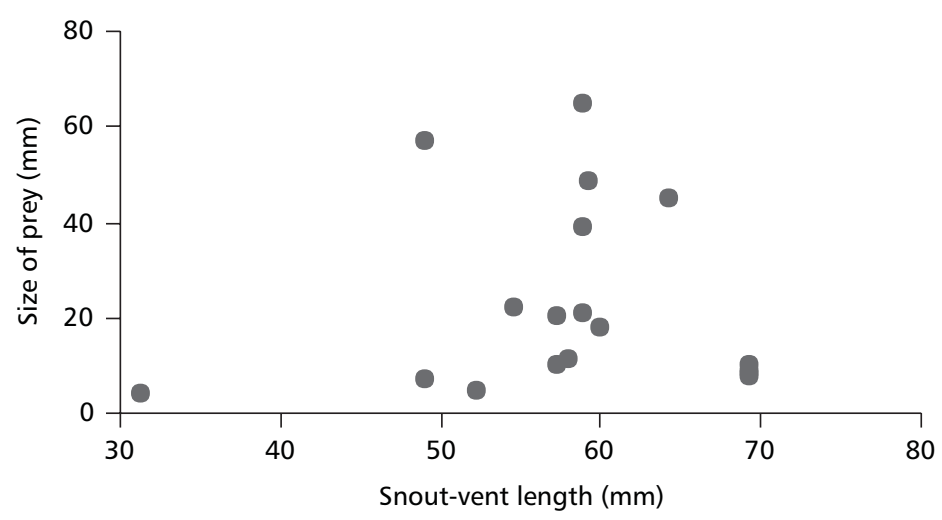

Fig. 2 - Variation in total length $(\mathrm{mm})$ of intact prey found in the stomach of A. brunoi from a restinga habita in southeastern Brazil.

\section{DISCUSSION}

Recent studies have shown that amphibian populations are declining in different environments around the world (Drost \& Fellers, 1996; Laurance et al., 1996; Lips, 1998, 1999; among others), a phenomenon that has been attributed to natural habitat destruction by human interference. This is clear along the Brazilian sandy coastal plains, where resort communities are increasing without regulation, before conservation plans can be implemented or even developed for protecting the natural vegetation. Deforestation almost always results in fragmentation of the original forest into isolated patches of habitat embedded in a modified matrix (Tocher et al., 1997). The same thing seems to be happening in the sandy coastal plains along the entire Brazilian coast.

Most studies assessing the fauna occupying bromeliads in that region have emphasized insect diversity (Laessle, 1961; Fish, 1976; Ferreira, 1981; Britto-Pereira et al., 1988a; Hadel, 1989; Oliveira et al., 1994), and a few have focused exclusively on the vertebrates using those habitats for shelter, feeding, and/or reproduction (Britto-Pereira, 1988b; Teixeira et al., 1997). No study, however, has yet concentrated on the vegetation decrease, such work could strongly contribute to development plans which would ensure habitat conservation, at least in part of the sandy coastal plains.

The amphibian community of Praia das Neves was represented by few species. All of them use the bromeliad as a diurnal shelter, and none reproduce inside the plant (see Peixoto, 1995).
The low specimen number could result from a disrupted environment. In restinga habitats of northeastern Espírito Santo, the hylid frog Phyllodytes luteolus, which spends its entire life cycle inside bromeliads (Peixoto, 1995), is the most abundant species (Teixeira et al., 1997). The number of species belonging to the genus Phyllodytes increases at lower latitudes in the sandy coastal plain. This suggests that the number of species using bromeliads during the entire life cycle increases northward in Brazil, probably due to temperature increase, and reduced availability of water. Amphibian species that use bromeliads southward of the municipality of Guarapari (Espírito Santo) become rare and do not depend on the bromeliad tank to reproduce. At Praia das Neves, most amphibian species appears to use the water accumulated in pools in the sand to reproduce.

Aparasphenodon brunoi is one of the largest frogs using bromeliads in order to survive on the sandy coastal plain. In other environments (e.g., Atlantic forest), this frog can find shelter in different microhabitats. Even though no information exists on its predators, the low abundance of this frog may be related to predating, or low tadpole survival, since fecundity is relatively high when compared to other hylid species. Although we do not have any evidence, the metamorphic duration for tadpoles of A. brunoi may be short, because the pools formed in the sand receive abundant sunlight, especially during the summer close to the beach line. As we found only one juvenile among all bromeliads analyzed, perhaps young animals hide in other 
habitats, since then could not be effectively protected in large bromeliads such as Aechmea lingulata.

Sex-ratio varied strongly between samples taken in the dry and in the rainy seasons. In the first, we collected more males, whereas in the rainy season we collected more females. However, we found only one pregnant female in the rainy season, and most females collected in the rainy season appeared to have already spawned, suggesting that the majority prefer to spawn in that period, thus assuring the success of egg development. If there are real sexratio differences during the spawning season peak, this may indicate either some competition between females in the effort to mate, or male promiscuity.

Aparasphenodon brunoi is a nocturnal species (Sazima \& Cardoso, 1980) that feeds on Orthoptera, Hemiptera, Diptera, and Coleoptera (Carvalho, 1939). Thus, as many other anurans, A. brunoi is an arthropod generalist able to consume allochthonous insects of bromeliads, but which may also hunt insects outside of bromeliad microhabitats.

Acknowledgments - We are indebted to José Manoel Gomes for identifying the bromeliads. Partial financial support was provided by the CNPq (Proc. No. 469321/2000-8). Special thanks to Davor Vrcibradic for criticism of an earlier version of the manuscript.

\section{REFERENCES}

ARGÔLO, A. J. S., 2000, Geographic distribution. Aparasphenodon brunoi. Herpetological Review, 31(2): 108.

BRITTO-PEREIRA, M. C., CERQUEIRA, R., SILVA, H. R. \& CARAMASHI, U., 1988a, Anfíbios anuros da restinga de Barra de Maricá, RJ: levantamento e observações preliminares sobre a atividade reprodutiva das espécies registradas. Anais do V Seminário Regional de Ecologia, São Carlos, SP, pp. 295-306.

BRITTO-PEREIRA, M. C., CERQUEIRA, R., SILVA, H. R. \& CARAMASHI, U., 1988b, Utilização de Neoregelia cruenta (Bromeliaceae) como abrigo diurno por anfíbios anuros na restinga de Barra de Maricá, RJ. Anais do V Seminário Regional de Ecologia, São Carlos, SP, pp. 307-318.

DEJEAN, A. \& OLMSTED, I., 1997, Ecological studies on Aechmea bracteata (Swartz) (Bromeliaceae). Journal of Natural History, 31: 1313-1334.

DROST, C. A. \& FELLERS, G. M., 1996, Collapse of a regional frog fauna in the Yosemite area of the California Sierra Nevada, USA. Conservation Biology, 10: 414-425.

DUELLMAN, W. E. \& TRUEB, L., 1994, Biology of amphibians. The Johns Hopkins University Press, Baltimore and London, 670p.

FEIO, R. N., BRAGA, U. M. L., WIEDERHECKER, H. \& SANTOS, P. S., 1998, Anfíbios do Parque Estadual do Rio Doce (Minas Gerais). Universidade Federal de Viçosa, Instituto Estadual de Florestas, 32p.
FERREIRA, C.P., 1981, Fauna associada às bromélias Canistrum aff. giganteum (Baker) L.B. Smith e Neoregelia cruenta (R. Grahan) L.B. Smith de restinga do litoral norte do Estado de São Paulo. Tese de estrado, Universidade Estadual de Campinas, Campinas, 97P., 3 Apêndices.

FISH, D., 1976, Structure and composition of the aquatic invertebrate community inhabiting epiphytic bromeliads in South America and the discovery of an insectivorous bromeliad. Ph.D. Dissertation, Florida State University, $78 \mathrm{p}$.

FROST, D. R., 1985. Amphibian species of the world. Allen Press, Lawrence.

HADDAD, C. F. B., 1998, Biodiversidade dos anfíbios no Estado de São Paulo. In: R. M. C. Castro (ed.), Biodiversidade do Estado de São Paulo, Brasil: síntese do conhecimento ao final do século XX, 6: Vertebrados. FAPESP, São Paulo, pp. 17-26.

HADEL, V. F., 1989, A fauna associada aos fitotelmata bromelícolas da estação ecológica de Juréia-Itatins (SP). Dissertação (Mestrado), Universidade de São Paulo, São Paulo, 128p.

LAESSLE, A. M., 1961, A microlimnological studies of Jamaican bromeliads. Ecology, 42: 499-517.

LAURANCE, W. F., McDONALD, K. R. \& SPEARE, R., 1996, Epidemic disease and the catastrophic decline of Australian rainforest frogs. Conservation Biology, 10: 406-413.

LIPS, K. R., 1998, Decline of a tropical montane amphibian fauna. Conservation Biology, 12: 1-13.

LIPS, K. R., 1999, Mass mortality and population declines of anurans at an upland site in western Panama. Conservation Biology, 13: 117-125.

OLIVEIRA, M. G. N., ROCHA, C. F. D. \& BAGNALL, T., 1994, The animal community associated with the tank bromeliad Neoregelia cruenta (R. Graham) L. B. Smith. Bromélia, 1(1): 22-29.

PEIXOTO, O. L., 1995, Associação de anuros e bromeliáceas na mata Atlântica. Rev. Univ. Rural, Sér. Ciênc. da Vida, 17(2): 75-83.

SAZIMA, I. \& CARDOSO, A. J., 1980, Notas sobre a distribuição de Corythomantis greeningi Boulenger, $1896 \mathrm{e}$ Aparasphenodon brunoi Miranda-Ribeiro, 1920 (Amphibia, Hylidae). Iheringia, Sér. Zool., Porto Alegre, 55: 3-7.

SILVA, S. P. C., IZECKSOHN, E. \& SILVA, A. M. P. T. C., 2000, Diversidade e ecologia de anfíbios em restingas do Sudeste brasileiro, pp. 89-97. In: F. A. Esteves \& L. D. Lacerda (eds.), Ecologia de restingas e lagoas costeiras. NUPEM/UFRJ, Macaé.

TEIXEIRA, R. L., ZAMPROGNO, C., ALMEIDA, G. I. \& SCHINEIDER, J. A., 1997, Tópicos ecológicos de Phyllodytes luteolus (Amphibia, Hylidae) da restinga de Guriri, São Mateus, ES. Rev. Brasil. Biol., 57(4): 647654.

TOCHER, M. D., GASCON, C. \& ZIMMERMAN, B. L., 1997, Fragmentation effects on a central Amazonian frog community: a ten-year study, pp. 124-137. In: W. F. Laurence \& R. O. Bierregaard Jr. (eds.), Tropical forest remnants: ecology, management, and conservation of fragmented communities, The University of Chicago Press, Chicago. 